\title{
Performance analysis of coconut enterprises facilitated through agribusiness incubators
}

\author{
T. Ashwini, Binoo P. Bonny* and S. Lokesh \\ Kerala Agricultural University, Thrissur-680 656, Kerala, India \\ (Manuscript Received: 25-04-2020, Revised: 14-08-2020, Accepted: 11-09-2020)
}

\begin{abstract}
Agribusiness incubators (ABI) catalyze entrepreneurship development by facilitating technology and institutionalized services. The study addresses the performance analysis of enterprises promoted through coconut sector ABIs working in Kerala. Primary and secondary data collected from 30 randomly selected ABI graduated entrepreneurs in business were used to characterize the enterprises. The results indicated that 56 per cent of enterprises joined ABIs at the nascent stage and were able to receive government funding under different subsidy schemes. Majority of enterprises $(72 \%)$ shared features of micro-enterprises in terms of the number of persons employed (01-10) and annual turnover less than ₹ 25 lakh. Most of the micro-enterprises (66\%) functioned as sole proprietary firms, whereas small enterprises were registered as limited company/partnership firms (20\%). Virgin coconut oil (VCO) was the major product in 40 per cent of enterprises followed by coconut chips $(20 \%)$, coconut chocolates $(10 \%)$, desiccated coconut (07), neera and tender coconut water-based drinks $(07 \%)$. Performances of two purposively selected enterprises producing VCO and coconut chips were undertaken using break-even analysis. Production and sales of both VCO and coconut chips were more than the calculated BEP values of 1000 litres and $500 \mathrm{~kg}$ respectively. This indicated that both enterprises operated at profitable levels. The findings suggest that the entrepreneurs who completed the business incubation program had greater success in their business irrespective of the business size. This can be attributed to their greater access to technologies and entrepreneurship development programmes under the ABI.
\end{abstract}

Keywords: Break-even analysis, entrepreneurship development, micro and small enterprises

\section{Introduction}

Congenial entrepreneurial ecosystem, which supports the entrepreneurs to take risks and operate the business at reasonable costs, is an essential prerequisite in the transformation of agriculture into agribusiness (Karuppanchetty et al., 2014). Agribusiness Incubators (ABIs) forms a significant institutional partner in the agribusiness ecosystem of India. The culture of entrepreneurship and innovation integration in ABIs was established in developed countries by a triple helix, an association of universities, companies and government (Machado et al., 2017). They serve as enablers that support and accelerate ideation, growth and development of agribusiness by facilitating technology, consultancy services, networking with experts, venture capital funding, infrastructure and other facilities (Baljeeth, 2014). In India, ABIs are the result of Agribusiness Incubation Program of 2003 which was an initiative of the International Crops Research Institute for Semi-Arid Tropics (ICRISAT) in partnership with the Department of Science and Technology (DST), Government of India (Sharma et al., 2014). To accelerate the transition of agriculture to agribusiness, Indian Council of Agricultural Research (ICAR) took this further forward under its National Agricultural Innovation Project (NAIP) by establishing 10 and 12 ABIs each, during 2008-09 and 2013-14, respectively, in India. These ABIs were established under agriculture research institutes and state agricultural universities where research on agricultural technologies was underway (Baljeeth, 2014). ABIs created an interface between the

*Corresponding Author: binoobonny@gmail.com 
research and development institutions, industries and financial institutions that aided in better commercialization of technologies (Karuppanchetty et al., 2014).

Ever since its inception, the main objective of ABIs has been to act as catalysts in entrepreneurship development by providing support for the creation of start-ups. These small and medium enterprises are capable of generating jobs, utilizing suitable technology, and creating wealth for economies (Ogutu and Kihonge, 2016). There have been many attempts to evaluate entrepreneurship development through ABIs. However, the performance of enterprises promoted through $\mathrm{ABIs}$ has remained largely under research. The study tries to address this gap by analyzing the performance of coconutbased enterprises which were facilitated by selected ABIs of Kerala.

\section{Material and methods}

The ex-post facto research design was followed in this study. Kerala was selected as the locale of the study for its leading area and production status in coconut. An exhaustive list of six ABIs working in Kerala was used to purposively select two ABIs that worked predominantly for the promotion of coconut-based enterprises viz., ABI-Central Plantation Crop Research Institute (CPCRI), Kasaragod and CIT-Coconut Development Board (CDB), Institute of Technology, Alwaye. List of graduated incubates from the ABIs was used to purposively select 15 enterprises currently in business from each of the two ABIs to make a total study sample of 30 working enterprises in the coconut sector. Personal interview using a semistructured schedule was used to collect information on the entrepreneurial and economic characters of the selected enterprises.

The performance indicators like the type of product, the technology used, the present stage of enterprise and markets covered related to enterprises facilitated by ABIs were selected based on literature search and expert consultancy. Data collected from records maintained by the selected enterprises on fixed and variable costs of production, the quantity of production and sales, sale prices and related information were used to assess the performance of these enterprises on selected major products viz., virgin coconut oil, and coconut chips. One representative enterprise, each with average values of production, sales and market for these major products and more than five years of business experience were used in performance assessment. Break-even analysis based on the assumption of constant input price, technology and selling price was used in the assessment. Estimation of breakeven point (BEP) followed the algebraic approach using equation (1).

$\mathrm{BEP}=\mathrm{F} / \mathrm{P}-\mathrm{V}$

$\mathrm{BEP}=$ break-even point; $\mathrm{F}=$ fixed cost for production; $\mathrm{P}=$ price per unit of product; $\mathrm{V}=$ variable cost per unit of product.

If the production and sales of the major product of the enterprises were more than the calculated BEP, such enterprises were considered as successful. If production and sales in the enterprises were less than the BEP, they were classified as less successful enterprises. Descriptive statistics like mean and percentages were also used in the analysis.

\section{Results and discussion}

The performance of coconut-based enterprises incubated and promoted through the ABIs was evaluated on entrepreneurial and economic characteristics selected through literature and expert consultancies. Social and entrepreneurial characteristics of entrepreneurs involved in coconutbased enterprises are presented in Table 1. The results indicated that the mean age of entrepreneurs was 42.31 years and ranged from 24-69 years. Moreover, 62 per cent of the coconut entrepreneurs had technical education with the majority having Engineering Diploma, and the education ranged from industrial training certificate to a Masters Degree in Engineering. Among the 38 per cent of entrepreneurs with general education majority were of higher secondary level of education and the range of general education level varied from $10^{\text {th }}$ class to post-graduation. Another important finding was that majority of 78 per cent were firstgeneration enterprises, and only 14 per cent had family inherited enterprises. NRIs and ex-employees constituted 4 per cent each of the total ABI facilitated enterprises in the coconut sector. Majority of enterprises in the coconut sector was in processing and value addition (84\%) and allied 
sector enterprises like coir pith composting. Agriculture service enterprise like coconut harvest using climbing machines covered 14 and 02 per cent, respectively. The predominance of processing and value addition enterprises validates the major role of food and agribusiness SMEs in global economic growth and development, particularly in the developing economies (Ayyagari et al., 2007; De and Nagaraj, 2014).

In terms of the stage of enterprise at the time of joining the ABI, 56 per cent were at the nascent stage which was at an ideational level, and 36 per cent belonged to the young category which was in informal marketing stage. There was only 08 per cent of mature level enterprises which sort the support of ABIs. They had started formal marketing of the product but were yet to make a profit and were facilitated by the ABIs. This indicates the proactive roles ABIs can assume in nurturing new enterprises rather than facilitating mature ones. Similarly, most micro-enterprises $(66 \%)$ were sole proprietary firms, whereas small enterprises were mostly limited company/partnership firms (20\%). Farmer producer organizations and service cooperatives were also present at seven per cent each. The results suggest a decisive role for micro and small enterprises in the strategic agricultural development as well as ensuring the profitability of the sector.

Coconut enterprises facilitated through the ABIs were also analyzed on selected technological and economic variables, and the results are given in Table 2. It could be observed that all the enterprises facilitated under ABIs received some form of financial assistance from government schemes. Maximum firms (28\%) benefited from

Table 1. Entrepreneurial characteristics of coconut enterprises facilitated through the ABIs (n=30)

\begin{tabular}{|c|c|c|}
\hline Sl. No. & Entrepreneurial characteristic (unit) & Mean (\%) \\
\hline \multirow[t]{4}{*}{1.} & Age of entrepreneurs (years) & $42.3(100)$ \\
\hline & Below 35 years (young) & $25.6(24)$ \\
\hline & Between 35-50 years (middle aged) & $41.8(58)$ \\
\hline & Above 50 years (seniors) & $59.5(18)$ \\
\hline \multirow[t]{3}{*}{2.} & Education level of entrepreneurs (type) & \\
\hline & General education & Higher Secondary (38) \\
\hline & Technical education & Engineering Diploma (62) \\
\hline \multirow[t]{5}{*}{3.} & Entrepreneurship status (frequency) & \\
\hline & First generation entrepreneurs & $24(78)$ \\
\hline & Family inherited entrepreneur & $04(14)$ \\
\hline & NRI returned entrepreneurs & $01(04)$ \\
\hline & Ex-employee turned entrepreneur & $01(04)$ \\
\hline \multirow[t]{4}{*}{4.} & Sector of enterprise (no.) & \\
\hline & Processing and value addition & $25(84)$ \\
\hline & Agricultural services & $01(02)$ \\
\hline & Allied activities (Coirpith-composting, mushroom etc) & $04(14)$ \\
\hline \multirow[t]{4}{*}{5} & Stage of enterprise at joining ABI (frequency) & \\
\hline & Nascent (Idea/ proven potential stage) & $17(56)$ \\
\hline & Young (Started informal marketing stage) & $11(36)$ \\
\hline & Mature (Started formal marketing but yet to make profit) & $02(08)$ \\
\hline \multirow[t]{5}{*}{6} & Type and registration & \\
\hline & Individual proprietorship & $20(66)$ \\
\hline & Limited liability partnership & $06(20)$ \\
\hline & Farmer producer company & $02(07)$ \\
\hline & Cooperatives & $02(07)$ \\
\hline
\end{tabular}


Table 2. Technological and economic features of coconut enterprises facilitated through the ABIs (n=30)

\begin{tabular}{llc}
\hline SI. No. & Entrepreneurial characteristic (unit) & Mean (\%) \\
\hline 1. & Sources of subsidized funding received (frequency) & $04(12)$ \\
& Entrepreneur Support Scheme (ESS) & $04(12)$ \\
& Procurement and Market Support Scheme (P and MSS) & $08(28)$ \\
& Prime Minister's Employment Generation Programme (PMEGP) & $07(24)$ \\
& Pradhan Mantri Mudra Yojana (PMMY) & $05(16)$ \\
& Technology Mission on Coconut (TMOC) & $02(08)$ \\
& Other funding with subsidies & $21(72)$ \\
& No. of workers employed per enterprise (frequency) & $05(16)$ \\
& 1-5 (Mean 3.24) & $04(12)$ \\
6-10 (Mean 7.4) & $12(40)$ \\
11- 50 and above (Mean 24) & $06(20)$ \\
Major products/services and technology adopted & $03(10)$ \\
Virgin coconut oil - Dry processing technology & $02(07)$ \\
Coconut chips - Osmotic dehydration and subsequent kernel drying & $02(07)$ \\
Coconut chocolates - Dry processing & $01(02)$ \\
Neera - Bottling technology with hygienic harvesting and processing & $04(14)$ \\
Desiccated coconut & \\
Coconut harvesting service - Coconut climbing machines & \\
Coir pith compost - biodegradation technology &
\end{tabular}

the Prime Minister's Employment Generation Programme (PMEGP) followed by 24 per cent under the Pradhan Mantri Mudra Yojana (PMMY). There were beneficiaries (12 per cent each) funded under the Entrepreneur Support Scheme (ESS) and Procurement and Market Support Scheme (P and MSS). However, none of the firms had a proper understanding of venture capital funding and how they could be benefited through it.

Majority of enterprises (72\%) had only 01-05 employees and micro enterprises with total investment below ₹ 25 lakhs. However, there were 6-10 employees working in 16 per cent of enterprises and 12 per cent that employed 11 to $>50$ which came under the category of small enterprises with investment between ₹ 25 lakhs and ₹ 5 crores. The result is attributed to the presence of Farmer Producer Companies (FPO) involved in neera processing. Some private virgin coconut oil companies also had high turnover.

The majority (40\%) of enterprises had virgin coconut oil (VCO) as their major product and mostly used dry processing technology. In terms of major products, coconut chips using osmotic dehydration technology and coconut chocolates followed at 20 and 10 per cent respectively. Neera and desiccated coconut were produced only by 07 per cent each of the enterprises.

Data from the VCO processing unit, Keratech Coconut Oil Manufacturing Pvt. Ltd, facilitated by the CDB-Institute of Technology, was used in breakeven analysis. It used the dry processing technology for product development and was marketed in the supermarkets of Kerala and exported to the countries, including the USA, Malaysia and Singapore. The enterprise was started in 2008 and had twenty employees. In addition to the VCO, the enterprise was producing natural hair cream.

Details of production and sales are given in Table 3. It indicates that the quantity of sales of VCO at Break-Even Point (BEP) was 1000 litres, and sales price ₹ 6 lakh (Fig. 1). The fixed cost was ₹ 20000 , variable cost per unit ₹ 580 and the selling price ₹ 600 per litre. The production and sales of VCO were more than the BEP of 1000 litres indicating profitability of the venture.

The coconut chips enterprise named 'Magic Co' facilitated by the ABI unit of CPCRI was selected 


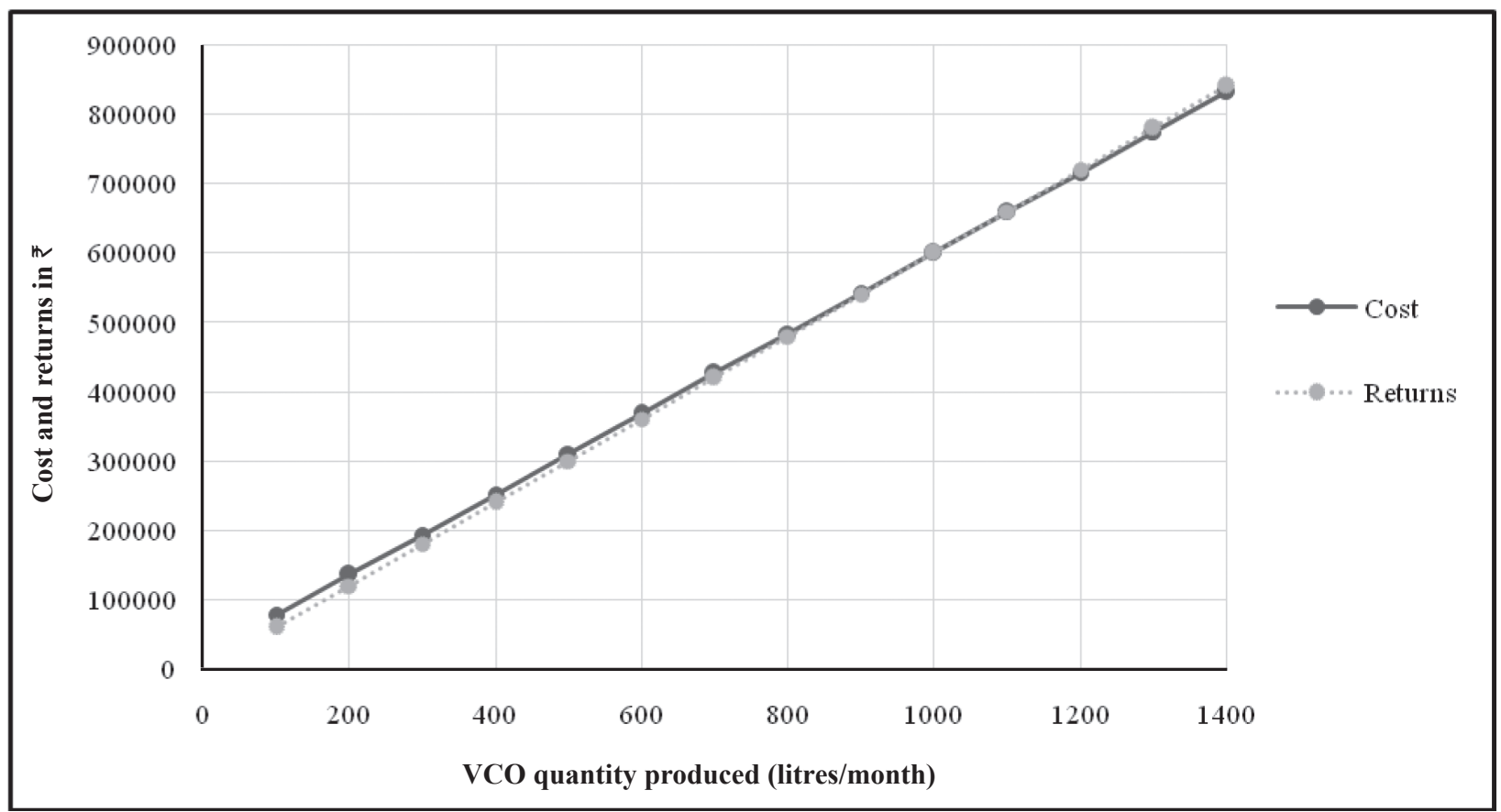

Fig 1. Break even analysis of Keratech VCO processing unit

Table 3. Components of Break Even Analysis of VCO

\begin{tabular}{lcccr}
\hline $\begin{array}{l}\text { Production } \\
\text { units (I) }\end{array}$ & $\begin{array}{c}\text { Fixed } \\
\text { cost } \\
\text { (₹) }\end{array}$ & $\begin{array}{c}\text { Variable } \\
\text { cost } \\
\text { (₹) }\end{array}$ & $\begin{array}{c}\text { Total } \\
\text { cost } \\
\text { (₹) }\end{array}$ & $\begin{array}{c}\text { Sales } \\
\text { price } \\
\text { (₹) }\end{array}$ \\
\hline 0 & 20,000 & 0 & 20,000 & 0 \\
100 & 20,000 & 58,000 & 78,000 & 60,000 \\
200 & 20,000 & $1,16,000$ & $1,36,000$ & $1,20,000$ \\
300 & 20,000 & $1,74,000$ & $1,94,000$ & $1,80,000$ \\
400 & 20,000 & $2,32,000$ & $2,52,000$ & $2,40,000$ \\
500 & 20,000 & $2,90,000$ & $3,10,000$ & $3,00,000$ \\
600 & 20,000 & $3,48,000$ & $3,68,000$ & $3,60,000$ \\
700 & 20,000 & $4,06,000$ & $4,26,000$ & $4,20,000$ \\
800 & 20,000 & $4,64,000$ & $4,84,000$ & $4,80,000$ \\
900 & 20,000 & $5,22,000$ & $5,42,000$ & $5,40,000$ \\
1000 & 20,000 & $5,80,000$ & $6,00,000$ & $6,00,000$ \\
1100 & 20,000 & $6,38,000$ & $6,58,000$ & $6,60,000$ \\
1200 & 20,000 & $6,96,000$ & $7,16,000$ & $7,20,000$ \\
\hline
\end{tabular}

for performance analysis as a standard unit of coconut chips with average values on selected parameters. It used osmotic dehydration and kernel drying technology and covered markets in Kerala, Delhi, Canada and USA. The Magic Co coconut chips enterprise was started in 2009. It had ten employees. Details of production and sales are given in Table 4. The production and sales of coconut chips were more than the BEP of $500 \mathrm{~kg}$, which is presented in Fig. 2. In addition to the coconut chips, the enterprise was producing coconut laddu with dry fruits, virgin coconut oil (VCO) and massaging oil. The production and sales values well above the $\mathrm{BEP}$ indicated that the unit was in profit.

Table 4. Components of break even analysis of coconut chips

\begin{tabular}{lcccr}
\hline $\begin{array}{l}\text { Production } \\
\text { units (kg) }\end{array}$ & $\begin{array}{c}\text { Fixed } \\
\text { cost } \\
(\boldsymbol{₹})\end{array}$ & $\begin{array}{c}\text { Variable } \\
\text { cost } \\
(\boldsymbol{₹})\end{array}$ & $\begin{array}{c}\text { Total } \\
\text { cost } \\
(\text { ₹) }\end{array}$ & $\begin{array}{c}\text { Sales } \\
\text { price } \\
(\text { ₹) }\end{array}$ \\
\hline 0 & 10,000 & 0 & 10,000 & 0 \\
100 & 10,000 & 8,000 & 18,000 & 10,000 \\
200 & 10,000 & 16,000 & 26,000 & 20,000 \\
300 & 10,000 & 24,000 & 34,000 & 30,000 \\
400 & 10,000 & 32,000 & 42,000 & 40,000 \\
500 & 10,000 & 40,000 & 50,000 & 50,000 \\
600 & 10,000 & 48,000 & 58,000 & 60,000 \\
700 & 10,000 & 56,000 & 66,000 & 70,000 \\
800 & 10,000 & 64,000 & 74,000 & 80,000 \\
900 & 10,000 & 72,000 & 82,000 & 90,000 \\
1000 & 10,000 & 80,000 & 90,000 & $1,00,000$ \\
\hline
\end{tabular}




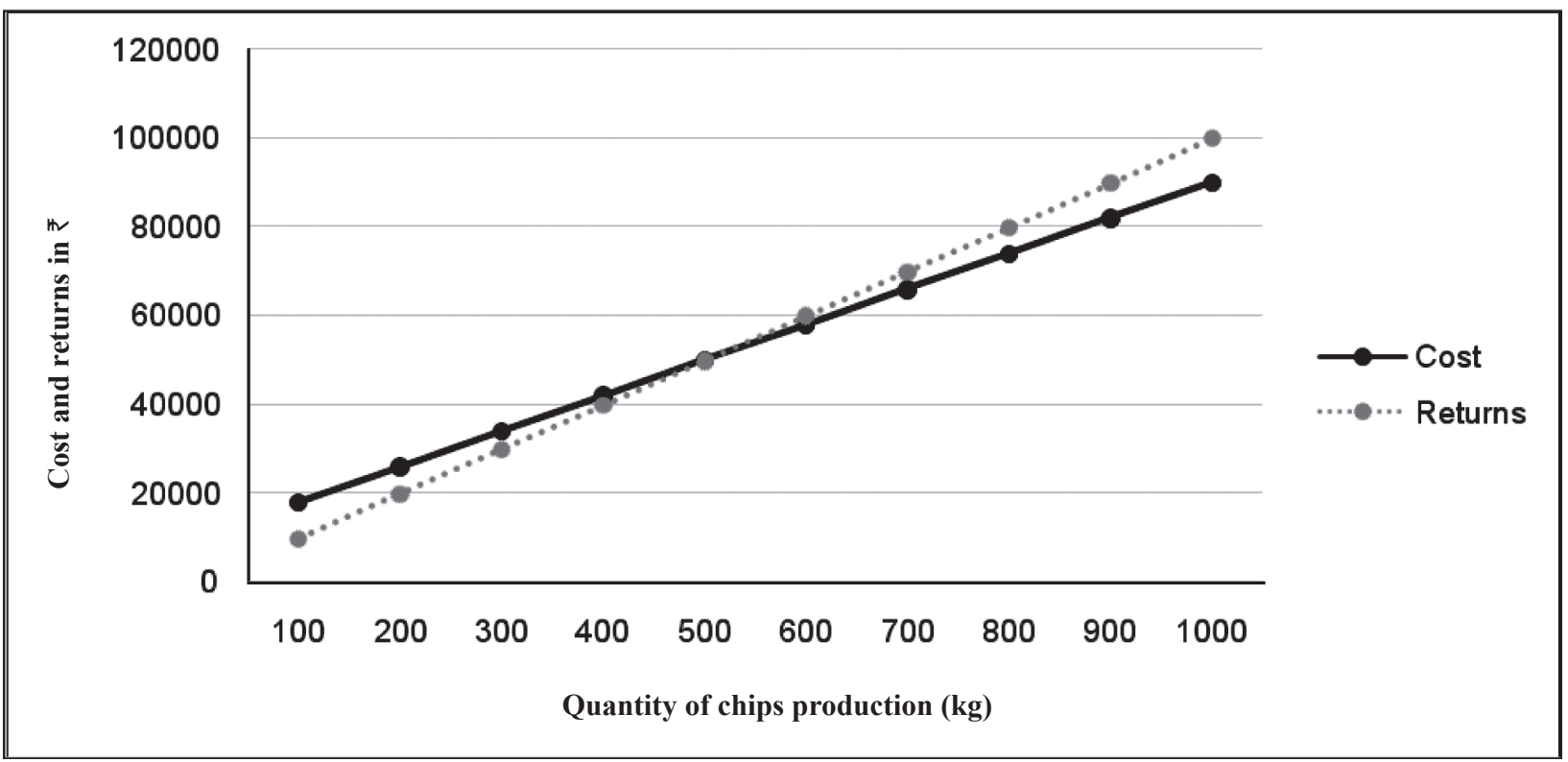

Fig 2. Break-even point quantity and costs of coconut chips

A comparison of BEP of virgin coconut oil and coconut chips, the major products of $\mathrm{ABI}$ incubated coconut enterprises is depicted in Table 5. This was calculated on the total fixed cost, the selling price of 10 months during 2018-19 as well as cost per unit of product sold (Zimmerer et al., 2005). Production and sales of both VCO and coconut chips were more than the calculated BEP values of 1000 litres and $500 \mathrm{~kg}$, respectively (Tables 3 and 4). This indicated that both the enterprises operated at profitable levels, as once the break-even point is achieved, the marginal turnover per unit of product sold is the profit (Potkany and Krajcirova, 2015).

Garret scores were used to rank the constraints faced by the entrepreneurs in availing the services of ABI. The results indicated that geographical remoteness of the location, inconsistency in providing the necessary support and lack of direct financial support with respective Garret scores of 239, 222 and 214 as the major challenges.
Hence policy measures to provide liaison offices of ABI's at various agro-parks, industrial-parks or district headquarters are recommended. This will enable better access of ABI resources to the entrepreneurs leading to sustainable entrepreneurship development.

\section{Conclusion}

Results in terms of economic contributions and the employment rate indicate that majority of enterprises incubated in ABIs came under the micro and small category as per MSME categorization. There were 88 per cent micro-enterprises with fewer than ten employees and an annual turnover less than ₹ 25 lakh and 12 per cent small enterprises with 11 to 50 and more employees and an annual turnover between ₹ 25 lakh to 5 crores. Moreover, all the enterprises studied irrespective of size had adequate access to government funds, licenses and quality control services, mostly facilitated through the ABIs,

Table 5. Comparison of BEP of major products of ABI incubated coconut enterprises

\begin{tabular}{lccccc}
\hline Product & $\begin{array}{c}\text { Fixed cost } \\
\text { (₹) }\end{array}$ & $\begin{array}{c}\text { Variable cost/unit } \\
\text { (₹) }\end{array}$ & $\begin{array}{c}\text { Selling price } \\
\text { (₹) }\end{array}$ & $\begin{array}{c}\text { Break even } \\
\text { point unit }\end{array}$ & $\begin{array}{c}\text { Break even point } \\
\text { (₹) }\end{array}$ \\
\hline Virgin coconut oil & 20000 & 580 & 600 & $1000 \mathrm{~L}$ & 600000 \\
Coconut chips & 10000 & 80 & 100 & $500 \mathrm{~kg}$ & 50000 \\
\hline
\end{tabular}


which indicated its follow up and continued support. These findings suggest that the entrepreneurs who completed the business incubation program had greater success in their business irrespective of the business size. This can be attributed to their greater access to technologies and entrepreneurship development programmes under the $\mathrm{ABI}$ program. The results iterate the critical role ABIs play in facilitating innovation, income generation and dynamism in the agricultural economy through micro and small enterprises.

\section{References}

Ayyagari, M., Beck, T. and Demirguc,-K. A. 2007. Small and medium enterprises across the globe. Small Business Economics 29: 415-434.

Baljeeth, S. 2014. Technology based entrepreneurship in agriculture - Role of agribusiness incubators. International Journal of Management and International Business Studies 4(3): 249-254.

De, P.K. and Nagaraj, P. 2014. Productivity and firm size in India. Small Business Economics 42: 891-907.

Karuppanchetty, S. M., Pandey, P. S., Philroy, J., Divya, N. G., Bhubesh, K. R., and Aravazhi, S. 2014. Agribusiness incubation transforming Indian agriculture: A business incubation approach of NAIP-BPDs in NARS. AgriBusiness Incubation Program of Agribusiness and Innovation Platform, International Crops Research Institute for the Semi-Arid Tropics, Telangana, India. $88 \mathrm{p}$.

Machado, A. B., Silva, A. R., and Bizzotto, C. E. N. 2017. Mapping of management model for business incubator. IOSR. Journal of Business Management 19(5): 28-34.

Ogutu, V. O. and Kihonge, E. 2016. Impact of business incubators on economic growth and entrepreneurship development. International Journal of Science and Research 8(5): 231-240.

Potkany, M. and Krajcirova, L. 2015. Quantification of the volume of products to achieve the Break-Even Point and desired profit in non-homogeneous production. Procedia Economics and Finance 26: 94-201.

Sharma, K. K., Karuppanchetty, S. M., and Aravazhi, S. 2014. Developing entrepreneurs through an agribusiness incubator at ICRISAT [Online]. Available: https:// inovationpolicyplatform.org/document/Module5/ Activityprofile1/pdf [5 Jan. 2018].

Zimmerer, T., Scarborough, N. M. and Wilson, D. 2005. Essentials of Entrepreneurship and Small Business Management. Pearson/Prentice Hall, New Jersey, $934 \mathrm{pp}$. 